\title{
Genetic analysis of lifetime productivity traits in goats
}

\author{
Marie-Rosa Wolber ${ }^{1}$, Henning Hamann ${ }^{2}$, and Pera Herold ${ }^{1,2}$ \\ ${ }^{1}$ Institute of Agricultural Sciences in the Tropics, University of Hohenheim, \\ Garbenstr. 17, 70599 Stuttgart, Germany \\ ${ }^{2}$ State Agency for Spatial Information and Rural Development Baden-Württemberg, \\ Stuttgarter Str. 161, 70806 Kornwestheim, Germany \\ Correspondence: Marie-Rosa Wolber (marierosa.wolber@uni-hohenheim.de)
}

Received: 21 February 2020 - Revised: 27 April 2021 - Accepted: 7 May 2021 - Published: 6 July 2021

\begin{abstract}
As part of the development of a breeding programme for dairy goats to support sustainable production in organic farming, the overall aim of the present study was to identify traits that can be used as selection criteria for lifetime productivity. The breeding goal is high lifetime productivity with a good milk composition and a good level of robustness in the animals, especially within grazing systems. The lifetime productivity traits analysed in this study were the length of the animal's productive life (LPL), the lifetime efficiency (LEF), and the animal's milk yield efficiency with respect the total number of lactating days (EDM); the average fat and protein content over the animal's lifetime, the fat-to-protein ratio (FPR), and the urea content (UC) were also included as indirect health traits and potential indicators of robustness in dairy goats. The traits' influencing factors, phenotypic and genetic correlations, and heritability were examined. Furthermore, factors influencing milk yield in the first $120 \mathrm{~d}$ of lactation during the animal's first lactation were analysed. The aim of investigating milk yield during the first lactation was to consider a connection between early performance recoding in the life of an animal and LPL, LEF, and EDM. In total, lactation and pedigree data from 9192 dairy goats of the common German Fawn (GF) and German White (GW) dairy breeds were used. Prerequisites were that the investigated birth cohorts had to have definitively completed their lifetime production, and a high proportion of goats had to have completed extended lactation. The data analysis showed that breed did not influence milk yield. The age at first kidding, the average number of kids born during the animal's lifetime, and the lactation length did influence the milk yield. This applies to the milk yield during the first $120 \mathrm{~d}$ of the first lactation as well as over the lifetime of an animal. Considering the influencing factors, the results showed that LPL was genetically and positively correlated with LEF and EDM $\left(r_{g}=0.65 \pm 0.06\right.$ and $0.29 \pm 0.07$ respectively). The heritability of LPL, LEF, and EDM was $0.22 \pm 0.02,0.29 \pm 0.03$, and $0.44 \pm 0.03$ respectively. Regarding the lifetime milk composition, the heritability of protein and fat content, FPR, and UC was $0.63 \pm 0.02,0.52 \pm 0.02,0.32 \pm 0.03$, and $0.47 \pm 0.04$ respectively. The heritability regarding the milk yield during the first $120 \mathrm{~d}$ of the first lactation was $0.34 \pm 0.03$. We found that the milk yield during the first $120 \mathrm{~d}$ of the first lactation showed a genetic correlation with LPL, LEF, and EDM of $0.30 \pm 0.08,0.82 \pm 0.04$, and $0.89 \pm 0.03$ respectively. In summary, LPL, LEF, and EDM are suitable traits to indicate lifetime productivity in dairy goats. An additional indicator for lifetime productivity could be the milk yield during the first $120 \mathrm{~d}$ of the first lactation. Moreover, FPR and UC appear to be promising indicator traits for the health and robustness of dairy goats. The present study showed the importance of considering extended lactation in selective breeding programmes as well as the importance of modelling extended lactation in the breeding value estimation.
\end{abstract}




\section{Introduction}

Breeding structures for dairy goats in Germany are poorly developed (Zumbach and Peters, 2007), and artificial insemination and structured breeding programmes currently do not exist. Compared with other livestock species, goat breeding in Germany is in its very early stages, and goat breeding organizations in the federal states of Bavaria and BadenWürttemberg only started to intensify their goat breeding programmes a few years ago. Herold et al. (2018) provides a brief overview of the goat breeding framework as well as recent developments. Despite the small breeding population, a breeding value estimation for the main two dairy goat breeds, German Fawn (GF) and German White (GW), was implemented in 2014. It was started using the available data from milk recording. Dairy goat farms in Germany are mainly organic (Herold et al., 2007; Manek et al., 2017); therefore, any attempts to improve the breeding structure in dairy goats must take the conditions and limitations of organic farming systems into account. The breeding goal is high lifetime productivity with a good milk composition and a good level of robustness in the animals, especially within grazing systems (Herold, 2016).

Additionally, breeding programmes should focus more on the robustness of dairy goats. Robustness describes the ability of an animal to maintain (high) production and wellbeing while being affected by different stressors (e.g. Friggens et al., 2017; Llonch et al., 2020). Robustness is a combination of multiple, interacting components (Friggens et al., 2017). It is difficult to define traits that reflect the biological mechanisms of robustness and that fulfil the requirements of selection traits (heritable, biologically meaningful, and repeatable). One possibility to describe robustness is to use biomarkers as indicators. In the present study, the fatto-protein ratio (FPR) and the urea content (UC) were used in such a manner. The FPR and UC are possible indicators of the animal's energy status or metabolic robustness (Buttchereit et al., 2011; König and May, 2019; Mäntysaari et al., 2019). Additionally, according to Friggens et al. (2017), longevity and lifetime efficiency are good measures of robustness in the same or similar environments.

Thus, the overall aim of the present study was to identify traits measured in regular milk recording that are suitable as selection criteria for lifetime productivity and robustness. For this reason, the traits' influencing factors, phenotypic and genetic correlations, and heritability were examined. Overall, the lifetime productivity traits investigated were the length of the animal's productive life (LPL), the lifetime efficiency (LEF), the animal's milk yield efficiency with respect the total number of lactating days (EDM), and the average fat and protein content over the animal's lifetime. Furthermore, factors influencing milk yield during the first $120 \mathrm{~d}$ of lactation during the animal's first lactation were analysed to consider a connection between the beginning of lactation and lifetime efficiency. In addition, an analysis was undertaken in order to establish if FPR and UC data from milk recording are suitable for use as robustness indicator traits.

\section{Materials and methods}

\subsection{Dairy goat breeding and husbandry in southern Germany}

According to Manek et al. (2017), most of the 35000 dairy goats in Germany are located in Bavaria, a federal state of Southern Germany. In 2020, 72 farms with a total of 5782 dairy goats participated in milk performance testing (LKV Bayern, 2020). At the same time, 2555 German Fawn goats from 41 farms and 1337 German White goats from 22 farms were registered in the herdbook of the Bavarian breeders association (Mendel, unpublished data). Dairy goat keeping as a fulltime farm activity and main source of income is relatively new and has developed over the last 25 years. The majority ( $81 \%$ ) of the goat farms in southern Germany (Baden-Württemberg and Bavaria) are organic operations (Kern, 2019).

With an increasing number of dairy goat farms and an increasing number of dairy plants processing goat milk, the number of days that an animal is kept lactating (and is milked) has increased in recent years. If milking continues for more than 1 year or even several years, lactation is characterized as "extended" (Moog et al., 2012). Extended lactation can occur before actual lactation, separated by a kidding. In addition, actual lactation can result in continuous milking and, therewith, in extended lactation. Major reasons for extended lactation are (1) that dairy plants demand a continuous supply of milk, and they pay better prices in autumn, and (2) there is no market for surplus kids (Ringdorfer, 2009). Therefore, extended lactation for several years can be an economically interesting option for dairy goat farms (Schuiling, 2007).

To date, lifetime productivity traits have not been investigated in German dairy goats. Working on lifetime productivity in an actual population means working with censored records. Therefore, the present study, as a pilot study for lifetime productivity traits in the German dairy goat population, deals with data from goats that have already ended their productive lifetime. The aim of this work was to estimate reliable variance components based on historical records. Unfortunately, this approach encountered two restrictions. The first restriction was that, due to the poorly developed breeding structures in the past, there was a high number of missing pedigrees in the records utilized. These data were available on paper, but they were not not available for data processing: unfortunately, there was neither the personnel nor the money available to digitize the data. The second restriction was the fact that extended lactation has become more common over the last 10 years. Data were restricted to records from the Bavarian goat herdbook because farmers in this federal state were the pioneers of extended milking in Germany (Herold 
et al., 2018). This guaranteed a preferably balanced data set of normal and extended lactation.

\subsection{Animals and material}

Data were provided by the Landeskuratorium der Erzeugerringe für tierische Veredelung in Bayern e.V. in Bavaria. This study included data from goats born between 1988 and 2006. Prematurely deceased animals were excluded from the data set. Data preparation and plausibility checks were carried out using SAS 9.4 (2017). In total, lactation data from 9192 dairy goats raised on 226 farms were examined. Overall, 145 farms kept German Fawn goats (GF; $n=3868$ ), 14 farms kept German White goats (GW; $n=103)$, and 67 farms kept both breeds ( $n=3860$ for GF and $n=1361$ for GW). Table 1 describes the data stratified by breed and farm size. The end of a goat's life was defined as the day it left the farm. If the animal did not leave the farm, either the last milk recording test day or the last recorded kidding was counted as the day of leaving. The first kidding age, as defined by Herold et al. (2018), was divided into two "classes of first kidding age" (Cfk): Cfk 1 was $\leq 620 \mathrm{~d}$ and Cfk 2 was $\geq 621 \mathrm{~d}$. For the GF breed, 180 sires and 2305 dams were recorded; for the GW breed, 52 sires and 355 dams were recorded. As such, information about the sire was available for 720 animals, and information about the dam was available for 3786 GF animals. Among the GW population, there were 153 dairy goats with sire information and 526 dairy goats with dam information. The ancestry of many animals was unknown, which was mainly due to the poorly developed data-processing structures in goat breeding. Goat pedigrees used to be stored on paper, and goat ear tag numbers have only been recorded digitally since the launch of a central database in 2009. Moreover, as a result of the livestock traffic ordinance put in place around this time, each dairy goat is now identified digitally using an individual animal number. Not all pedigree data for dairy goats born before 2009 have been digitized, and some identification numbers were not clearly assignable. Table 2 shows the data structure of the investigated dairy goats. Targeted lifetime productivity traits were the length of the animal's productive life (LPL), the lifetime efficiency (LEF), the animal's milk yield efficiency with respect the total number of lactating days (EDM), and the average fat and protein content over the animal's lifetime. Further, milk yield during the first $120 \mathrm{~d}$ of lactation during the animal's first lactation was examined. The traits were defined as follows: LPL (in days) was the time period from first kidding to the last information available for the animal, LEF was lifetime milk yield (in $\mathrm{kg}$ per day), and EDM was the efficiency per day with respect to milk yield per day of lactation (in $\mathrm{kg}$ per day). LEF includes rearing and dry-off periods, because lifetime milk yield implies that the rearing phase is included. LPL includes the dryoff period. EDM describes the animal's milk yield efficiency with respect the total number of lactating days and contains neither the rearing nor dry-off periods. Due to the prerequi- site that all investigated goats had completed their lifetime productivity, information was available on total production per goat and on the length of the lifetime of each goat.

LPL, LEF, and EDM were chosen due to the different considerations in relation to the rearing and dry-off periods. In addition to examining the milk yield and the protein and fat content during lactation, the fat-to-protein ratio (FPR; the quotient between fat and protein content as a percentage) and the urea content (UC; in $\mathrm{mg} / 100 \mathrm{~mL}$ ) in milk were examined as part of the milk recording. In the data evaluation, extended lactation was examined. Extended lactation is becoming increasingly common as a method of milking animals over a long period without requiring them to birth offspring (Moog et al., 2012; Sehested et al., 2019). This practice could be an influencing factor on the lifetime traits examined, which is why it has been taken into account in the present investigation. The standard lactation length is $240 \mathrm{~d}$ (Herold et al., 2018). In a "normal" goat's life, one $365 \mathrm{~d}$ cycle with an annual kidding consists of a maximum lactation period of $305 \mathrm{~d}$ days and a non-lactation period of $60 \mathrm{~d}$. Thus, the gestation period comprises 150 lactating days and a non-lactation period. As such, lactation was considered to be extended if the animal was lactating for more than $305 \mathrm{~d}$. For more information on extended lactation in goats, see Wolber et al. (2018, 2019). Goats in the present data set predominantly underwent extended lactation during their second lactation (Wolber et al., 2018). Some goats were milked longer than $720 \mathrm{~d}$. In the present work, the days of extended lactation over an animal's lifetime were calculated pro rata with respect to the total lactation days. These proportions were grouped into four extended lactation (EL) classes: $\mathrm{EL}=0 \%, 0<\mathrm{EL} \leq 50 \%$, $50<\mathrm{EL}<100 \%$, and $\mathrm{EL}=100 \%$. Lactation traits and the number of kids in a goat's lifetime are also shown in Table 2. Table 3 shows the milk yield in the first $120 \mathrm{~d}$ of lactation during the animal's first lactation, the first kidding age (in days), the number of kids, and the proportion of animals that underwent extended lactation during their first lactation.

\subsection{Statistical analysis - analysis of variance}

An analysis of variance was carried out using the SAS 9.4 (2017) statistical program and the SAS MIXED procedure. This was to determine which factors influenced LPL, LEF, and EDM. A pairwise difference test (PDIFF) was used to investigate the significant differences in trait expression $(p<0.05)$. The following model equation was used to analyse factors influencing the lifetime output:

$$
\begin{aligned}
Y_{i j k l m n} & =\mu+B_{i}+\mathrm{By}_{j}+\mathrm{Cfk}_{k}+\mathrm{Ls}_{l}+\mathrm{El}_{m} \\
& +\operatorname{farm}_{n}+e_{i j k l m n} .
\end{aligned}
$$

Here, $Y_{i j k l m n}$ denotes the observed lifetime productivity traits (LPL, LEF, and EDM), the average fat and protein content over the animal's lifetime, and the FPR and UC indicator traits. $B_{i}$ is the fixed effect of the breed ( $i$ can be 1 or 2 , where 
Table 1. Number of dairy goats and number of farms by breed and farm size.

\begin{tabular}{lrr|rr|rr}
\hline Farm size & \multicolumn{2}{c|}{ GF $^{*}$} & \multicolumn{2}{c|}{ GW $^{*}$} & \multicolumn{2}{c}{ Mixed GF and GW } \\
\cline { 2 - 6 } (No. goats per farm) & No. goats & No. farms & No. goats & No. farms & No. goats (GF, GW) & No. farms \\
\hline $1-10$ & 374 & 97 & 52 & 13 & 56,38 & 16 \\
$10-20$ & 245 & 18 & 0 & 0 & 134,90 & 15 \\
$21-50$ & 493 & 14 & 0 & 0 & 77,139 & 6 \\
$51-100$ & 265 & 4 & 51 & 1 & 740,251 & 15 \\
$101-250$ & 1442 & 9 & 0 & 0 & 883,782 & 10 \\
$251-600$ & 1049 & 3 & 0 & 0 & 1970,61 & 5 \\
No. observations & 3868 & 145 & 103 & 14 & 3860,1361 & 67 \\
\hline
\end{tabular}

* GF and GW denote the German Fawn and German White breeds respectively.

Table 2. Data collected over a dairy goat's lifetime by breed.

\begin{tabular}{|c|c|c|c|c|}
\hline \multirow[t]{2}{*}{ Data structure } & \multicolumn{2}{|c|}{$\mathrm{GF}^{\mathrm{a}}(n=7728)$} & \multicolumn{2}{|c|}{$\mathrm{GW}^{\mathrm{a}}(n=1464)$} \\
\hline & $\bar{X}$ & SD & $\bar{X}$ & SD \\
\hline Length of productive life (LPL; in days) & 1146.70 & 901.87 & 976.84 & 763.26 \\
\hline Lifetime efficiency (LEF; in kg) & 1.06 & 0.55 & 0.98 & 0.53 \\
\hline Milk yield efficiency with respect the total number of lactating days (EDM; in $\mathrm{kg}$ ) & 2.38 & 0.79 & 2.52 & 0.83 \\
\hline Prot. cont. (\%) & 3.29 & 0.29 & 3.32 & 0.26 \\
\hline Fat cont. $(\%)$ & 3.56 & 0.54 & 3.51 & 0.48 \\
\hline Fat-to-protein ratio (FPR) & 1.08 & 0.15 & 1.06 & 0.12 \\
\hline Urea content $(\mathrm{UC})^{\mathrm{b}}$ & 47.15 & 8.98 & 49.42 & 7.71 \\
\hline No. kids per dairy goat within the animal's lifetime ${ }^{c}$ & 1.85 & 0.51 & 1.79 & 0.50 \\
\hline Proportion of extended lactation $(\%)^{\mathrm{d}}$ & 24.74 & 34.86 & 24.14 & 35.57 \\
\hline
\end{tabular}

${ }^{\mathrm{a}} \mathrm{GF}$ and GW denote the German Fawn and German White breeds respectively. ${ }^{\mathrm{b}}$ Reduced number of data available: $n=4951$ (GF) and $n=827$ (GW). ${ }^{\mathrm{c}}$ Reduced number of data available: $n=7535(\mathrm{GF})$ and $n=1375(\mathrm{GW}){ }^{\mathrm{d}}$ Days of extended lactation over an animal's lifetime were calculated pro rata with respect to the total lactation days, and the proportions were grouped into four extended lactation (EL) classes: $\mathrm{EL}=0 \%, 0 \%<\mathrm{EL} \leq 50 \%, 50 \%<\mathrm{EL}<100 \%$, and $\mathrm{EL}=100 \%$.

GF is denoted by 1 , and $\mathrm{GW}$ is denoted by 2 ), $\mathrm{By}_{j}$ is the fixed effect of the birth year ( $j$ ranges from 1 to 19 , denoting the years from 1988 to 2006 respectively), $\mathrm{Cfk}_{k}$ is the fixed effect of the class of the first kidding age $(k$ can be 1 or 2 , where $\mathrm{Cfk} \leq 620 \mathrm{~d}$ is 1 and $\mathrm{Cfk} \geq 621 \mathrm{~d}$ is 2 ), Ls is the fixed effect of litter size (lifetime average; $l$ ranges from 1 to 3 , where a litter size of 1 is denoted by 1 , a litter size $>1$ is denoted by 2 , and an unknown litter size is denoted by 3 ), $\mathrm{El}_{m}$ is the fixed effect of extended lactation with respect to total days lactating ( $m$ ranges from 1 to 4 , where $\mathrm{EL}=0 \%$ is denoted by $1,0 \%<\mathrm{EL} \leq 50 \%$ is denoted by $2,50 \%<\mathrm{EL}<100 \%$ is denoted by 3 , and $\mathrm{EL}=100 \%$ is denoted by 4$)$, farm $n$ is the random effect of the farm ( $n$ ranges from 1 to 226), and $e_{i j k l m n}$ is the residual error. The following model equation was used to analyse factors influencing milk production in the first $120 \mathrm{~d}$ of lactation during the animal's first lactation:

$$
\begin{aligned}
Y_{i j k l m n} & =\mu+B_{i}+\mathrm{By}_{j}+\mathrm{Cfk}_{k}+\mathrm{Ls}_{l}+\mathrm{El}_{-} 1_{m} \\
& +\operatorname{farm}_{n}+e_{i j k l m n} .
\end{aligned}
$$

Here, $Y_{i j k l m n}$ is the milk yield in the first $120 \mathrm{~d}$ during the animal's first lactation, $B_{i}$ is the fixed effect of the breed ( $i$ can be 1 or 2 , where GF is denoted by 1 , and GW is denoted by 2), $\mathrm{By}_{j}$ is the fixed effect of the birth year ( $j$ ranges from 1 to 19 , denoting the years from 1988 to 2006 respectively), $\mathrm{Cfk}_{k}$ is a fixed effect of the class of first kidding age ( $k$ can be 1 or 2 , where $\mathrm{Cfk} \leq 620 \mathrm{~d}$ is 1 and $\mathrm{Cfk} \geq 621 \mathrm{~d}$ is 2 ), Ls1 ${ }_{l}$ is the fixed effect of litter size at first kidding ( $l$ ranges from 1 to 3 , where a litter size of 1 is denoted by 1 , a litter size $>1$ is denoted by 2 , and an unknown litter size is denoted by $3)$, El_ $1_{m}$ is the fixed effect of extended lactation from the first lactation ( $m$ can be 1 or 2 , where standard lactation is 1 and extended lactation is 2 ), farm ${ }_{n}$ is the random effect of the farm ( $n$ ranges from 1 to 226), and $e_{i j k l m n}$ is the residual error.

\subsection{Statistical analysis - estimation of variance components}

Genetic parameters were estimated by using an animal model and applying the restricted maximum likelihood (REML) approach in VCE 6 software (Groeneveld et al., 2010). As part of the REML process, only converged estimations with a status of one were used in the multivariate estimation runs. The following model equation was used to estimate the variance components: 
Table 3. Data structure of dairy goats during the first $120 \mathrm{~d}$ of the first lactation.

\begin{tabular}{|c|c|c|c|c|}
\hline \multirow[t]{2}{*}{ Data structure } & \multicolumn{2}{|c|}{$\mathrm{GF}^{\mathrm{a}}(n=7728)$} & \multicolumn{2}{|c|}{$\mathrm{GW}^{\mathrm{a}}(n=1464)$} \\
\hline & $\bar{X}$ & SD & $\bar{X}$ & SD \\
\hline Milk yield (kg) & 281.49 & 109.06 & 299.25 & 107.05 \\
\hline First kidding age (in days) & 517.59 & 210.29 & 608.95 & 265.05 \\
\hline No. of kids during first lactation ${ }^{b}$ & 1.72 & 0.62 & 1.67 & 0.59 \\
\hline Proportion of extended lactation during first lactation $(\%)^{\mathrm{c}}$ & 18.0 & 39.0 & 19.0 & 40.0 \\
\hline
\end{tabular}

${ }^{\mathrm{a}} \mathrm{GF}$ and GW denote the German Fawn and German White breeds respectively. ${ }^{\mathrm{b}}$ Reduced number of data available: $n=7532$ (GF) and $n=1375(\mathrm{GW}) .{ }^{\mathrm{c}}$ Days of extended lactation over an animal's lifetime were calculated pro rata with respect to the total

lactation days, and the proportions were grouped into four extended lactation (EL) classes: $\mathrm{EL}=0 \%, E \leq 50 \%, \mathrm{EL}<100 \%$, and $\mathrm{EL}=100 \%$

$$
\begin{aligned}
Y_{i j k l m n o} & =\mu+B_{i}+\mathrm{Cfk}_{j}+\mathrm{Ls}_{k}+\mathrm{El}_{-} 1_{l}+b \cdot \mathrm{Sel}_{-} \mathrm{lif}_{m} \\
& +\operatorname{hby}_{n}+a_{o}+e_{i j k l m n o} .
\end{aligned}
$$

Here, $Y_{i j k l m n o}$ denotes the observed lifetime productivity traits (LPL, LEF, and EDM), the average fat and protein content over the animal's lifetime, and the FPR and UC indicator traits. $B_{i}$ is the fixed effect of the breed ( $i$ can be 1 or 2 , where GF is 1 and GW is 2), $\mathrm{Cfk}_{j}$ is a fixed effect of the class of the first kidding age ( $j$ can be 1 or 2 , where $\mathrm{Cfk} \leq 620 \mathrm{~d}$ is 1 and $\mathrm{Cfk} \geq 621 \mathrm{~d}$ is 2 ), $\mathrm{Ls}_{k}$ is the fixed effect of litter size (lifetime average; $l$ can be 1 or 2 , where a litter size of 1 is 1 and litter size $>1$ is 2), and $\mathrm{El}_{m}$ is the fixed effect of extended lactation with respect to total days lactating $(\mathrm{m}$ ranges from 1 to 4 , where $\mathrm{EL}=0 \%$ is $1,0 \%<\mathrm{EL} \leq 50 \%$ is $2,50 \%<\mathrm{EL}<100 \%$ is 3, and $\mathrm{EL}=100 \%$ is 4$)$. The linear regression includes the linear regression coefficient $(b)$ and the covariable Sel_lif $m$ (proportion of days lactating that are classified as extended lactation). The random effects are $\operatorname{hby}_{n}$, which is the herd birth year $(n=1.085)$, and $a_{o}$, which is the additive genetic effect of the animal $(n=1-25,450)$. The residual error is $e_{i j k l m n o}$.

The following model equation was used to estimate the variance components for milk yield in the first $120 \mathrm{~d}$ of the first lactation:

$$
\begin{aligned}
Y_{i j k l m n o} & =\mu+B_{i}+\mathrm{Cfk}_{j}+\mathrm{Ls}_{k}+\mathrm{El}_{-} 1_{l}+b \cdot \text { Sel_lif }_{m} \\
& +\mathrm{hky}_{n}+a_{o}+e_{i j k l m n o} .
\end{aligned}
$$

Here, $Y_{i j k l m n o}$ is the milk yield in the first $120 \mathrm{~d}$ during the first lactation. $B_{i}$ is the fixed effect of the breed ( $i$ can be 1 or 2 , where GF is 1 and GW is 2 ), Cfk ${ }_{j}$ is a fixed effect of the class of the first kidding age ( $j$ can be 1 or 2 , where $\mathrm{Cfk} \leq 620 \mathrm{~d}$ is 1 and Cfk $\geq 621 \mathrm{~d}$ is 2 ), $\mathrm{Ls} 1_{k}$ is the fixed effect of litter size at first kidding $(l$ can be 1 or 2 , where a litter size of 1 is 1 and litter size $>1$ is 2), El_ $1_{l}$ is the fixed effect of extended lactation from the first lactation ( $m$ can be 1 or 2 , where standard lactation is 1 and extended lactation is 2 ). The linear regression includes the linear regression coefficient $(b)$ and the covariable Sel_lif $m$ (proportion of days lactating that are classified as extended lactation). The random effects are hky_ $1_{m}$, which is the random effect of the herd kidding year of the first lactation $(m=948)$, and $a_{o}$, which is the additive genetic effect of the animal $(n=1-25,450)$. The residual error is $e_{i j k l m n o}$.

\section{Results}

\subsection{Influence on lifetime productivity traits}

The results of the analysis of variance are summarized in Table 4. Breed had no significant effect on lifetime productivity traits. First kidding age showed significant effects on the LEF and EDM: when goats kidded for the first time at more than $620 \mathrm{~d}$, the LEF decreased by $0.14 \mathrm{~kg}$ and the EDM increased by $0.06 \mathrm{~kg}$. An average litter size larger than one had significantly positive effects on the LEF and EDM. Apart from the FPR, extended lactation had a significant effect on all traits studied. If less than $50 \%$ of the days lactating during the animal's lifetime were extended lactation, the phenotypically highest LPL, LEF, and EDM could be achieved, with values of $1415.58 \mathrm{~d}, 1.30 \mathrm{~kg}$, and $3.08 \mathrm{~kg}$ respectively. If an animal had no extended lactation, significantly lower LSM (least squares mean) values were observed for LPL, LEF, and EDM, with values of $435.37 \mathrm{~d}, 0.76 \mathrm{~kg}$, and $2.90 \mathrm{~kg}$ respectively. Animals without extended lactation during their lifetime had the significantly lowest LPL and LEF, with values of $435.37 \mathrm{~d}$ and $0.76 \mathrm{~kg}$. The EDM was not significantly different from animals with $100 \%$ extended lactation $(2.90 \mathrm{~kg}$ vs. $2.88 \mathrm{~kg}$ ).

The milk components were affected differently, which is also reflected in the effects on FPR. The average protein content over the animals' lifetime (in \%) was influenced by the litter size class and by the intensity of extended lactation. An average litter size larger than one had a significant positive effect on the protein content (in \%) of the milk. Goats with with $100 \%$ extended lactation showed the highest protein content of $3.36 \%$. Fat content (in \%) was also significantly affected by the intensity of extended lactation. As for protein, goats with $100 \%$ extended lactation had the highest fat content of $3.45 \%$. The FPR during the animals' lifetime was significantly affected by both breed and the litter size 
Table 4. LSM values during the dairy goats' lifetime.

\begin{tabular}{|c|c|c|c|c|c|c|c|c|c|c|c|c|c|c|c|}
\hline \multirow{2}{*}{$\begin{array}{l}\text { Factor levels during } \\
\text { lifetime }\end{array}$} & \multirow[t]{2}{*}{ No. obs. } & \multicolumn{2}{|c|}{ LPL } & \multicolumn{2}{|c|}{ LEF } & \multicolumn{2}{|c|}{ EDM } & \multicolumn{2}{|c|}{ Prot. cont. (\%). } & \multicolumn{2}{|c|}{ Fat cont. (\%) } & \multicolumn{2}{|c|}{ FPR } & \multicolumn{2}{|c|}{$\mathrm{UC}^{*}$} \\
\hline & & LSM & SE & LSM & SE & LSM & SE & LSM & SE & LSM & SE & LSM & SE & LSM & SE \\
\hline GF & 7728 & $996.53^{\mathrm{a}}$ & 34.45 & $1.10^{\mathrm{a}}$ & 0.03 & $2.94^{\mathrm{a}}$ & 0.06 & $3.29^{\mathrm{a}}$ & 0.01 & $3.60^{\mathrm{a}}$ & 0.03 & $1.09^{\mathrm{a}}$ & 0.01 & $46.87^{\mathrm{a}}$ & 0.88 \\
\hline GW & 1464 & $962.32^{\mathrm{a}}$ & 40.48 & $1.11^{\mathrm{a}}$ & 0.03 & $2.98^{\mathrm{a}}$ & 0.06 & $3.31^{\mathrm{b}}$ & 0.01 & $3.56^{\mathrm{a}}$ & 0.03 & $1.08^{\mathrm{b}}$ & 0.01 & $47.47^{\mathrm{a}}$ & 0.92 \\
\hline Birth year (1988-2006) & 9192 & & & & & & & & & & & & & & \\
\hline Cfk $1: \leq 620 \mathrm{~d}$ & 6578 & $970.38^{\mathrm{a}}$ & 36.00 & $1.17^{\mathrm{a}}$ & 0.03 & $2.93^{\mathrm{a}}$ & 0.06 & $3.30^{\mathrm{a}}$ & 0.01 & $3.57^{\mathrm{a}}$ & 0.03 & $1.08^{\mathrm{a}}$ & 0.01 & $47.25^{\mathrm{a}}$ & 0.88 \\
\hline $\mathrm{Cfk} 2: \geq 621 \mathrm{~d}$ & 2614 & $988.48^{\mathrm{a}}$ & 36.34 & $1.03^{\mathrm{b}}$ & 0.03 & $2.99^{\mathrm{b}}$ & 0.06 & $3.31^{\mathrm{a}}$ & 0.01 & $3.59^{\mathrm{a}}$ & 0.03 & $1.09^{\mathrm{a}}$ & 0.01 & $47.09^{\mathrm{a}}$ & 0.89 \\
\hline Litter size $=1$ & 3336 & $877.99^{\mathrm{a}}$ & 37.10 & $1.03^{\mathrm{a}}$ & 0.03 & $2.77^{\mathrm{a}}$ & 0.06 & $3.28^{\mathrm{a}}$ & 0.01 & $3.58^{\mathrm{a}}$ & 0.03 & $1.09^{\mathrm{a}}$ & 0.01 & $47.09^{\mathrm{a}}$ & 0.89 \\
\hline Litter size $>1$ & 5571 & $1308.97^{\mathrm{a}}$ & 32.82 & $1.32^{\mathrm{b}}$ & 0.03 & $2.96^{\mathrm{b}}$ & 0.06 & $3.30^{\mathrm{b}}$ & 0.01 & $3.56^{\mathrm{a}}$ & 0.03 & $1.08^{\mathrm{b}}$ & 0.01 & $47.06^{\mathrm{a}}$ & 0.86 \\
\hline $\mathrm{EL}=0 \%$ & 5587 & $435.37^{\mathrm{a}}$ & 33.97 & $0.76^{\mathrm{a}}$ & 0.03 & $2.90^{\mathrm{a}}$ & 0.06 & $3.24^{\mathrm{a}}$ & 0.01 & $3.52^{\mathrm{a}}$ & 0.03 & $1.09^{\mathrm{a}}$ & 0.01 & $46.75^{\mathrm{a}}$ & 0.88 \\
\hline $0 \%<\mathrm{EL} \leq 50 \%$ & 1323 & $1416.58^{\mathrm{b}}$ & 39.54 & $1.30^{\mathrm{b}}$ & 0.03 & $3.08^{\mathrm{c}}$ & 0.06 & $3.29^{\mathrm{b}}$ & 0.01 & $3.56^{\mathrm{b}}$ & 0.03 & $1.08^{\mathrm{a}}$ & 0.01 & $47.32^{\mathrm{ab}}$ & 0.90 \\
\hline $50 \%<\mathrm{EL}<100 \%$ & 1496 & $1242.49^{\mathrm{c}}$ & 39.15 & $1.25^{\mathrm{c}}$ & 0.03 & $2.98^{\mathrm{b}}$ & 0.06 & $3.32^{\mathrm{c}}$ & 0.01 & $3.60^{\mathrm{c}}$ & 0.03 & $1.09^{\mathrm{a}}$ & 0.01 & $47.39^{\mathrm{b}}$ & 0.90 \\
\hline $\mathrm{EL}=100 \%$ & 786 & $823.28^{d}$ & 41.79 & $1.11^{\mathrm{d}}$ & 0.03 & $2.88^{\mathrm{a}}$ & 0.06 & $3.36^{\mathrm{d}}$ & 0.01 & $3.64^{\mathrm{c}}$ & 0.03 & $1.08^{\mathrm{a}}$ & 0.01 & $47.21^{\mathrm{ab}}$ & 0.92 \\
\hline No. obs. & & 9192 & & & & & & & & & & & & & \\
\hline
\end{tabular}

a, b, c, d Indices within the traits show significant differences at the $p<0.05$ level. The lifetime productivity traits are as follows: length of productive life (LPL; in days), lifetime efficiency (LEF; in kg), milk yield efficiency with respect the total number of lactating days (EDM; in kg), protein content (prot. cont.; in \%), fat content (fat cont.; in \%),

fat-to-protein ratio (FPR), and urea content in milk (UC; in $\mathrm{mg} / 100 \mathrm{~mL}$ ). The factor levels are as follows: class of first kidding age (Cfk) and proportion of extended lactation in the animals total lactation (EL). * Measurements taken over the time span from 1995 to $2006(n=5778) .{ }^{* * *} p<0.05$.

class. GF had a higher FPR than GW (1.09 vs. 1.08), and goats with an average litter size of one showed a higher FPR than goats with an average litter size larger than one (1.09 vs. 1.08). The UC during the animals' lifetime was significantly affected by the share of extended lactation. Goats with no extended lactation had a lower UC than goats with a share of extended lactation between $>50$ and $<100 \%$ (46.75 vs. 47.39).

\subsection{Influence on milk yield during the first $120 \mathrm{~d}$ of lactation}

The results of the analysis of variance are shown in Table 5 . The analysis of variance showed that breed had no influence on milk yield (in $\mathrm{kg}$ ) during the first $120 \mathrm{~d}$ of the first lactation. The first kidding class had a significant influence on the milk yield in the first $120 \mathrm{~d}$ of lactation during the first lactation. Dairy goats that had their first kid at more than $620 \mathrm{~d}$ old yielded significantly more milk in the first $120 \mathrm{~d}$ of lactation than animals that were younger than $620 \mathrm{~d}$ at first kidding $(+24.85 \mathrm{~kg})$. The litter size at first kidding had a significant influence on milk yield during the first $120 \mathrm{~d}$ of lactation during the first lactation: if the litter size was larger than one at the first kidding, the milk yield increased by $26.33 \mathrm{~kg}$ during the first $120 \mathrm{~d}$ of lactation. Dairy goats that were selected for an extended first lactation had a significantly higher milk yield (19.72 $\mathrm{kg}$ more) during the first $120 \mathrm{~d}$ of lactation.

\subsection{Estimation of variance components}

The phenotypic and genetic correlations between lactation yields during the first lactation and over the animals' lifetime are presented in Table 6; the $P$ values are shown in Table 7 . The milk yield during the first lactation period had a low phenotypic correlation with LPL, LEF, and EDM of 0.07, 0.23,
Table 5. LSM values during the first $120 \mathrm{~d}$ of the first lactation in dairy goats.

\begin{tabular}{lrrr}
\hline Factor levels during first lactation & No. obs. & \multicolumn{2}{c}{ Milk yield 1-120 DIM } \\
\cline { 3 - 4 } & & LSM & SE \\
\hline GF & 7728 & $342.33^{\mathrm{a}}$ & 7.27 \\
GW & 1464 & $347.93^{\mathrm{a}}$ & 7.83 \\
Birth year (1988-2006) & 9192 & & $* * *$ \\
Cfk 1: $\leq 620 \mathrm{~d}$ & 6578 & $332.70^{\mathrm{a}}$ & 7.41 \\
Cfk 2: $\geq 621 \mathrm{~d}$ & 2614 & $357.55^{\mathrm{b}}$ & 7.44 \\
Litter size $=1$ & 3336 & $330.86^{\mathrm{a}}$ & 7.30 \\
Litter size $>1$ & 5571 & $357.19^{\mathrm{b}}$ & 7.22 \\
EL_1: no & 7500 & $335.27^{\mathrm{a}}$ & 7.28 \\
EL_1: yes & 1692 & $354.99^{\mathrm{b}}$ & 7.59 \\
No. observations & 9192 & & \\
\hline
\end{tabular}

a, b, c, d Indices within the traits show significant differences at the $p<0.05$ level. Production trait: milk yield during the first $120 \mathrm{~d}$ of lactation (DIM). Factor levels: German Fawn (GF) and German White (GW) breeds; class of first kidding age (Cfk); extended lactation during first lactation (EL_1), where "no" denotes that the first lactation was a standard lactation, and "yes" denotes that first lactation was an extended lactation. SE denotes standard error. ${ }^{* * *} p<0.05$.

and 0.27 respectively. The milk yield during the first lactation had a high genetic correlation with LEF and EDM (0.82 and 0.89 respectively). With a value of 0.30 , the correlation between the milk yield in the first lactation and LPL was moderately positive. The genetic correlations of LPL with LEF and EDM were positive ( 0.65 and 0.29 respectively). The respective genetic correlations of milk protein content (\%), milk fat content (\%), FPR and UC with the LEF trait were in a negative middle range, with respective values of $-0.23,-0.34$, -0.32 and -0.17 . Heritability of lifetime productivity traits are summarized diagonally (using bold font) in Table 6; the $P$ values are shown diagonally (using bold font) in Table 7 . Heritability of LPL, LEF, and EDM was 0.22, 0.29, and 0.44 respectively. For protein and fat content $(\%)$, heritability was 
Table 6. Heritability, additive genetic correlations, and phenotypic correlations between lifetime productivity traits and milk yield during the first $120 \mathrm{~d}$ of lactation.

\begin{tabular}{|c|c|c|c|c|c|c|c|c|}
\hline Traits & LPL & LEF & EDM & $\begin{array}{r}\text { Prot. cont. } \\
(\%)\end{array}$ & $\begin{array}{r}\text { Fat cont. } \\
(\%)\end{array}$ & FPR & UC & $\begin{array}{l}\text { Milk yield } \\
1-120 \text { DIM }\end{array}$ \\
\hline LPL & $\mathbf{0 . 2 2}(0.02)$ & $0.65(0.06)$ & $0.29(0.07)$ & $0.03(0.06)$ & $-0.12(0.07)$ & $-0.25(0.08)$ & $-0.24(0.08)$ & $0.30(0.08)$ \\
\hline EDM & $0.08(0.02)$ & $0.60(0.03)$ & $0.44(0.03)$ & $-0.37(0.05)$ & $-0.40(0.06)$ & $-0.29(0.08)$ & $-0.11(0.07)$ & $0.89(0.03)$ \\
\hline Prot. cont. (\%) & $0.01(0.03)$ & $-0.08(0.03)$ & $-0.16(0.02)$ & $\mathbf{0 . 6 3}(0.02)$ & $0.73(0.03)$ & $0.21(0.06)$ & $0.16(0.06)$ & $-0.34(0.06)$ \\
\hline Fat cont. $(\%)$ & $0.03(0.03)$ & $-0.11(0.03)$ & $-0.12(0.03)$ & $0.49(0.04)$ & $\mathbf{0 . 5 2}(0.02)$ & $0.83(0.02)$ & $0.15(0.07)$ & $-0.25(0.07)$ \\
\hline $\begin{array}{l}\text { Milk yield } \\
1-120 \text { DIM }\end{array}$ & $0.07(0.02)$ & $0.23(0.03)$ & $0.27(0.02)$ & $-0.09(0.02)$ & $-0.09(0.03)$ & $-0.05(0.03)$ & $-0.02(0.03)$ & $\mathbf{0 . 3 4}(0.03)$ \\
\hline
\end{tabular}

Heritability (on the diagonal line denoted using bold font), additive genetic correlations (above the diagonal line denoted using bold font), and phenotypic correlations (below the diagonal line denoted using bold font), with the standard errors given in parentheses. Lifetime productivity traits: length of productive life (LPL; in days), lifetime efficiency (LEF; in $\mathrm{kg}$ ), milk yield efficiency with respect the total number of lactating days (EDM; in kg), protein content (prot. cont.; in \%), fat content (fat cont.; in \%), fat-to-protein ratio (FPR), urea content in milk (UC; in $\mathrm{mg} / 100 \mathrm{~mL}$ ), milk yield during the first $120 \mathrm{~d}$ of lactation (DIM) during the first lactation. $n=9067$.

0.63 and 0.52 respectively. The heritability of FPR and UC was 0.32 and 0.47 respectively. The heritability for milk yield in the first $120 \mathrm{~d}$ of lactation was 0.34 .

\section{Discussion}

\subsection{Data set restrictions}

The data structure is rather disparate. For example, in the GF group, $89 \%$ of farms had $\leq 50$ goats, whereas $71 \%$ of goats were kept on farms with $>50$ goats. Due to a high amount of natural mating, the genetic links between different herds are low. This is a general problem in genetic studies on German goat breeds, as described by Herold et al. (2018). In addition, the present data set contains a large number of animals with unknown or only partly known ancestry $(90 \%$ of sires and $50 \%$ of dams are missing). Zumbach et al. (2004, 2008) also encountered identification problems in their data from German goat breeding associations and could only use half of the delivered test day data for analyses. The inhomogeneous data structure and missing pedigree information can lead to an underestimation of genetic relationships within the population. Animals with unknown pedigree are assigned to phantom parents that are assumed to be unrelated. In a population with many missing records, as in our case, it is likely that relations between animals are underestimated due to missing information. Thus, these assumptions can lead to an overestimation of heritability. The standard errors in the calculations are also potentially greater, and the results can be slightly distorted and, thus, overrated or underrated. It is important to consider this background when interpreting the results. The goat population under focus is rather small; therefore, estimation of genetic parameters is difficult and still somewhat imprecise. However, for dairy goat farmers genetic gain in the goat breeding programme is important in order to increase the goats lifetime productivity and, in turn, ensure their income. The present work is a pilot study using available practical data. It can be seen as the beginning of work toward targeted breeding. Further studies will concentrate on the actual population and will include data from other breeding organizations. In the actual population, genetic relationships are better documented and the problem should be negligible.

\subsection{Influencing factors}

Class of first kidding age had a significant effect on LEF and EDM. Due to the extended rearing phase, during which an animal creates costs but does not achieve any returns, later first kidding ( $\geq 620 \mathrm{~d}$ ) has a negative effect on LEF. In contrast, later kidding has a positive effect on EDM. This is similar to findings in dairy cattle, such as those by Berry and Cromie (2009), Eastham et al. (2018), and Sawa et al. (2019). In the above-mentioned studies, cows with a lower age at first calving had higher odds of survival and subsequent parities. The studies concluded that a lower age at first calving is associated with an increased lifetime daily milk yield. Depending on their internal goals, goat dairy farms must individually decide how old the animals should be at first kidding. Factors influencing the decision in this context are rearing costs, the intensity of dairy goat production on the farm, and the goal of a long productive life for the animals. If there is the potential to generate economic income from landscape conservation before the first kidding, for example, this can be an argument for later kidding (e.g. in the second year of life) if the income from landscape conservation is similar to the potential profit from milk sale during this time.

Animals with a higher milk yield during the first $120 \mathrm{~d}$ of lactation were more frequently chosen for extended lactation. Lehmann et al. (2017) report corresponding results for dairy cows: milk yield at the second and third milk recording during the first lactation is a good indicator of the suitability of a cow for extended lactation. Additionally, a high persistency in late lactation (around day 240-300) is a basis for the de- 
Table 7. $P$ values for heritability and phenotypic and genetic correlations between lifetime productivity traits and milk yield during first $120 \mathrm{~d}$.

\begin{tabular}{lrrrrrrrr}
\hline Traits & LPL & LEF & EDM & $\begin{array}{r}\text { Prot. cont. } \\
(\%)\end{array}$ & $\begin{array}{r}\text { Fat cont. } \\
(\%)\end{array}$ & FPR & UC & $\begin{array}{r}\text { Milk yield } \\
1-120 \text { DIM }\end{array}$ \\
\hline LPL & $\mathbf{< . 0 0 1}$ & $<0.001$ & $<0.001$ & 0.573 & 0.089 & 0.003 & 0.003 & $<0.001$ \\
LEF & $<0.001$ & $<\mathbf{0 . 0 0 1}$ & $<0.001$ & $<0.001$ & $<0.001$ & $<0.001$ & 0.048 & $<0.001$ \\
EDM & $<0.001$ & $<0.001$ & $<\mathbf{0 . 0 0 1}$ & $<0.001$ & $<0.001$ & $<0.001$ & 0.129 & $<0.001$ \\
Prot. cont. (\%) & 0.765 & 0.001 & $<0.001$ & $\mathbf{< 0 . 0 0 1}$ & $<0.001$ & 0.001 & 0.009 & $<0.001$ \\
Fat cont. (\%) & 0.303 & $<0.001$ & $<0.001$ & $<0.001$ & $<\mathbf{0 . 0 0 1}$ & $<0.001$ & 0.028 & $<0.001$ \\
FPR & 0.247 & 0.022 & 0.237 & 0.077 & $<0.001$ & $<\mathbf{0 . 0 0 1}$ & 0.240 & 0.305 \\
UC & 0.090 & 0.461 & 0.900 & $<0.001$ & $<0.001$ & 0.001 & $<\mathbf{0 . 0 0 1}$ & 0.010 \\
Milk yield & 0.002 & $<0.001$ & $<0.001$ & 0.001 & 0.003 & 0.150 & 0.507 & $<\mathbf{0 . 0 0 1}$ \\
1-120 DIM & & & & & & & &
\end{tabular}

$P$ values for heritability (on the diagonal line denoted using bold font), additive genetic correlations (above the diagonal line denoted using bold font), phenotypic correlations (below the diagonal line denoted using bold font), and lifetime productivity traits: length of productive life (LPL; in days), lifetime efficiency (LEF; in kg), milk yield efficiency with respect the total number of lactating days (EDM; in kg), protein content (prot. cont.; in \%), fat content (fat cont. \%; in \%), fat-to-protein ratio (FPR), urea content in milk (UC; in $\mathrm{mg} / 100 \mathrm{~mL}$ ), and milk yield during first $120 \mathrm{~d}$ of lactation (DIM) during the first lactation. $n=9067$.

cision of whether lactation should be extended or the animal should be dried off (Herold et al., 2019). Furthermore, it was found that animals that had extended lactation of $>0 \%$ to $\leq 50 \%$ achieved significantly higher LSM values for LPL, LEF, and EDM. These goats had short extended lactation of less than 2 years. It is likely that rebreeding was delayed for goats in this class, in order to utilize their full performance capacity. This is similar to findings on extended lactation in high-production dairy cows, where extended lactation lasts around 16 months (Sehested et al., 2019). With this strategy, extended lactation can be used to reduce offspring but still use animals with high genetic potential for reproduction.

\subsection{Lifetime productivity traits}

Data analysis showed that the milk yield during the first $120 \mathrm{~d}$ of lactation was phenotypically positively correlated with the lifetime productivity traits. A highly positive phenotypic correlation between the first and following lactation was also reported by Mucha et al. (2014). The milk yield at the beginning of the first lactation was positively correlated at both a phenotypic and a genetic level with LPL, LEF, and EDM. This was also confirmed in Wangler et al. (2009) for dairy cows. Milk yield is included in all of the examined traits; therefore, there is a high overlap with lifetime productivity traits. Genetic correlations between LPL, LEF, and EDM or the milk quantity during the first $120 \mathrm{~d}$ of lactation were in a middle to high positive range. This is favourable concerning the breeding programme, but careful consideration is required regarding which traits will be used for selection. In terms of the milk composition, the genetic correlations between LEF, EDM, and milk yield during the first $120 \mathrm{~d}$ of lactation, and the milk protein and fat content were - as in Boichard et al. (1989) and Torres-Vázquez et al. (2009) - in the middle negative range. This underpins the fact that protein and fat content need to be included in the selection index to ensure genetic gain in these traits. Goat milk is mainly used for cheese production, and milk solids are important components. The heritability of LPL was in the middle range at 0.24 . In a study by Castañeda-Bustos et al. (2014), the estimated heritability for productive life (72 months maximum) was also in the middle range at 0.22 . The heritability for LEF has previously been described in Geddes et al. (2018) using the average lifetime daily milk yield, and a value of 0.46 was estimated. In the investigated population, the heritability for LEF was lower (0.31). The highest heritability determined in Boichard et al. (1989), Torres-Vázquez et al. (2009), Rupp et al. (2011), and Castañeda-Bustos et al. (2014), as well as in the present investigation, was for lifetime protein and fat content. The heritability of the first $120 \mathrm{~d}$ of lactation in the present investigation was similar to the heritability of milk yield during the first lactation of 0.34 reported in Desire et al. (2018). This differs from the results of Zumbach et al. $(2004,2008)$ on the same German breeds. They estimated a heritability of 0.28 for milk yield from day 91 to 120 during the first lactation. They used a larger data set than the present study, 36144 test day records for the first lactation of goats from six breeding associations, including Bavarian data. For $62 \%$ of the studied animals, the complete pedigrees were known. As already described above, this difference might be a hint that heritability in the present study might be overestimated.

Sustainable production includes ecological and economic as well as social and ethical aspects (IFOAM, 2015). A long and productive lifetime fulfils all four criteria. An increased LPL is interesting from an economic point of view (Fekete et al., 2012; Schuster et al., 2020; de Vries and Marcondes, 2020). Increasing LPL would support the attainment of an animal's physiological peak, which, according to Bömkes et al. (2004a, b) and Gall (2001), is in the third to fourth lactation for dairy goats. Studies by Wangler et al. (2009) and Eil- 
ers (2014) showed that dairy cows also leave the herd before reaching their peak milk yield. If an animal does not reach its physiological peak due to a previous selection, this reduces the chance that it can recuperate the costs of its rearing phase, which is generally a negative from an economic point of view. Furthermore, results from a study on cattle showed that older animals seem to develop digestive and metabolic strategies to make more efficient use of nutritional energy than younger animals (Grandl et al., 2017). In terms of feed efficiency, which can affect the sustainability and profitability of a system, it would be interesting to investigate how the metabolic strategies of dairy goats change with advancing age. Additionally, a high LPL can be a component to reduce greenhouse gas emission in dairy production (Knapp et al., 2014; Grandl et al., 2019; de Vries and Marcondes, 2020). A high LPL can also be an indicator of animal welfare, of good integration in the herd, and of a high ability to cope with the farm's environmental conditions (Schuster et al., 2020; de Vries and Marcondes, 2020). Therefore, LPL also covers social and ethical aspects of sustainable dairy production.

The LEF trait essentially covers the economic aspect of lifetime productivity and implies the rearing phase, the dry phase, and the length of productive life. Rearing and dry phases that are too long have a negative effect on the LEF and also have the potential to negatively affect the profitability, as the costs of feeding and care are not balanced out by performance (Wangler et al., 2009; Eilers, 2014). Many studies on dairy cattle indicate that the length and quality of the rearing period are decisive for milk performance in the first lactation and for lifetime productivity (e.g. Le Cozler et al., 2008; Mohd Nor et al., 2013; Volkmann et al., 2019). Therefore, selection for the LEF has to consider age and body development at first insemination (Handcock et al., 2019; Volkmann et al., 2019). According to these different studies in dairy cattle, it might have negative effects on animal welfare and on profitability if animals are too young at the start of their first lactation. Extended lactation can support the LEF (Sehested et al., 2019). Different authors argue that extended lactation has a positive effect on cows' health - for example, by avoiding stressful calving and the risk of metabolic diseases (e.g. Sehested et al., 2019; Römer et al., 2020). In addition, with extended lactation, less calves or kids are born and have to be reared and marketed. This takes some of the weight off the market and off the farmers (Ringdorfer, 2009; Sehested et al., 2019).

In addition to the milk yield of the dam, milk yield during the first $120 \mathrm{~d}$ of the first lactation could be a reliable indicator when estimating a lifetime productivity breeding value early on. Data in the present study were limited to goats that had already left the herd. To calculate a breeding value or breeding value index, the results of the present study must be transferred to the actual population.

\subsection{Biomarker as indicators of dairy goat health}

In the present study, the average FPR values were at the lower bound of the optimum range of 1.0 to $<1.5$ according to Rahmann (2007). The FPR is negatively genetically correlated with lifetime productivity. This is favourable in the context of the breeding programme. The data analysis showed that the LSM of lifetime UC exceeded the limits recommended by Bellof and Weppert (1996) and von Korn et al. (2013), but they were lower than in Criscioni et al. (2016). Criscioni et al. (2016) found that the UC is higher in late lactation than in early lactation. Von Korn et al. (2013) stated that the trend in UC is more meaningful than single values. In the present study, UC is negatively genetically correlated with the lifetime productivity traits, which is favourable with respect to the breeding programme. With high lifetime productivity, UC will decrease, which will have a positive effect on animal health, the environment, and sustainability (Rensing et al., 2019). The results for the FPR and UC biomarkers are promising regarding using them as indicators of dairy goat health in the breeding programme. Both parameters are generated from routine milk recording and could serve as selection criteria for metabolic stability, as is already implemented in dairy cattle breeding (Buttchereit et al., 2011, 2012; Koeck et al., 2014; König and May, 2019). Additionally, a goat herd health data recording system was implemented to collect direct health data on farms (Herold et al., 2017), and data are slowly accumulating. In the future, when more direct health data are available and can be combined with the FPR and UC from milk recording, health traits can be incorporated into breeding value estimation and the breeding programme.

\section{Conclusions}

In summary, LPL, LEF, and EDM are suitable traits to indicate lifetime productivity in dairy goats. It is now up to the breeding associations to decide which traits should be implemented in the breeding programme. It would also be possible to create an index of different lifetime productivity traits. An additional indicator for lifetime productivity could be the milk yield during the first $120 \mathrm{~d}$ of the first lactation. The FPR and UC are promising indicator traits of health and robustness in dairy goats. The present study showed the importance of considering extended lactation in the breeding programme as well as modelling extended lactation in breeding value estimation. Research in dairy cattle support the fact that extended lactation can improve animal welfare and reduce the number of offspring. In dairy goats, more research is needed on the correlations between extended lactation and health and robustness traits.

Data availability. The data are available upon reasonable request from the corresponding author. 
Author contributions. PH designed the study, acquired financing, and directed and supervised the project. MRW performed the statistical analysis and wrote the paper. HH supported the statistical analysis and interpretation of the results.

Competing interests. The authors declare that they have no conflict of interest.

Acknowledgements. The authors would like to thank the Bundesministerium für Ernährung und Landwirtschaft for supporting the GoOrganic project within the framework of the "Federal Scheme for Organic Farming and Other Forms of Sustainable Agriculture, the Landeskuratorium der Erzeugerringe für tierische Veredelung in Bayern e.V. for providing the milk records, and the Landesverband Bayerischer Ziegenzüchter e.V. for providing the pedigree data.

Financial support. This research was supported by the Federal Ministry of Food and Agriculture within the framework of the Federal Scheme for Organic Farming and Other Forms of Sustainable Agriculture (grant no. 15NA027).

Review statement. This paper was edited by AntkeElsabe Freifrau von Tiele-Winckler and reviewed by two anonymous referees.

\section{References}

Bellof, G. and Weppert, M.: Die Beurteilung der Energieund Eiweißversorgung bei der Milchziege mit Hilfe von Milchharnstoff- und Milcheiweißgehalt [The assessment of energy and protein supply in the dairy goat using milk urea and milk protein content], Der Ziegenzüchter, 6, 3-12, 1996.

Berry, D. P. and Cromie, A. R.: Associations between age at first calving and subsequent performance in Irish spring calving Holstein-Friesian dairy cows, Livest. Sci., 123, 44-54, https://doi.org/10.1016/j.livsci.2008.10.005, 2009.

Boichard, D., Bouloc, N., Ricordeau, G., Piacere, A., and Barillet, F.: Genetic parameters for first lactations dairy traits in the Alpine and Saanen goat breeds, Genet. Sel. Evol., 21, 205-215, https://doi.org/10.1186/1297-9686-21-2-205, 1989.

Bömkes, D., Hamann, H., and Distl, O.: Einfluss systematischer Umwelteffekte auf die Milchleistungsmerkmale bei Bunten Deutschen Edelziegen, Arch. Anim. Breed., 47, 275-285, https://doi.org/10.5194/aab-47-275-2004, 2004a.

Bömkes, D., Hamann, H., and Distl, O.: Populationsgenetische Analyse von Milchleistungsmerkmalen bei Weißen Deutschen Edelziegen [Population genetic analysis of milk yield traits in German White], Züchtungskunde, 76, 127-138, $2004 \mathrm{~b}$.

Buttchereit, N., Stamer, E., Junge, W., and Thaller, G.: Short communication: Genetic relationships among daily energy balance, feed intake, body condition score, and fat to protein ratio of milk in dairy cows, J. Dairy Sci., 94, 1586-1591, https://doi.org/10.3168/jds.2010-3396, 2011.
Buttchereit, N., Stamer, E., Junge, W., and Thaller, G.: Genetic parameters for energy balance, fat/protein ratio, body condition score and disease traits in German Holstein cows, J. Anim. Breed. Genet., 129, 280-288, https://doi.org/10.1111/j.14390388.2011.00976.x, 2012.

Castañeda-Bustos, V. J., Montaldo, H. H., Torres-Hernández, G., Pérez-Elizalde, S., Valencia-Posadas, M., Hernández-Medno, O., and Shepard, L.: Estimation of genetic parameters for productive life, reproduction, and milk production traits in US dairy goats, J. Dairy Sci., 97, 2462-2473, https://doi.org/10.3168/jds.20137503, 2014.

Criscioni, P., Larsen, T., and Fernández, C.: Milk metabolites as biomarkers of energy balance in goats during lactation, in: Energy and protein metabolism and nutrition, edited by: Skomia, J. and Lapierre, I., EAAP Scientific Series, Vol. 137, Wageningen Academic Publishers EAAP Scientific Series, 123-124, 2016.

Desire, S., Mucha, S., Coffey, M., Mrode, R., Broadbent, J., and Conington, J.: Pseudopregnancy and aseasonal breeding in dairy goats: genetic basis of fertility and impact on lifetime productivity, Animal, 12, 1799-1806, https://doi.org/10.1017/S1751731117003056, 2018.

de Vries, A. and Marcondes, M. I.: Review: Overview of factors affecting productive lifespan of dairy cows, Animal, 14, 155164, https://doi.org/10.1017/S1751731119003264, 2020.

Eastham, N. T., Coates, A., Cripps, P., Richardson, H., Smith, R., and Oikonomou, G.: Associations between age at first calving and subsequent lactation performance in UK Holstein, Plos One, 13, e0197764, https://doi.org/10.1371/journal.pone.0197764, 2018.

Eilers, U.: Lebensleistung und Lebenseffektivität - eine Analyse zur Optimierung wichtiger Parameter für nachhaltige Milcherzeugung [Lifetime performance and lifetime effectivity - an analysis for optimization of essential parameters of sustainable milk production], in: 41. Viehwirtschaftliche Fachtagung des Lehrund Forschungszentrum für Landwirtschaft (LFZ), RaumbergGumpenstein, Austria, 9-10 April 2014, 45-53, 2014.

Fekete, Z., Baumung, R., Fuerst-Waltl, B., Keller, K., and Szabo, F.: Einfluss des Milchertrags auf Betriebsrentabilität und ökonomische Gewichte von ausgewählten Merkmalen [The effect of milk yield on the profitability and economic weight of selected traits], Züchtungskunde, 84, 463-473, 2012.

Friggens, N. C., Blanc, F., Berry, D. P., and Puillet, L.: Review: Deciphering animal robustness. A synthesis to facilitate its use in livestock breeding and management, Animal, 11, 2237-2251, https://doi.org/10.1017/S175173111700088X, 2017.

Gall, C.: Ziegenzucht [Goat breeding], Eugen Ulmer GmbH \& Co., Stuttgart, Germany, 2001.

Geddes, L., Desire, S., Mucha, S., Coffey, M., Mrode, R., and Conington, J.: Genetic parameters for longevity traits in UK dairy goats, in: Proceeding of the World Congress on Genetics Applied to Livestock Production, New Zealand, 547 pp., available at: https://hdl.handle.net/10568/98465 (last access: 25 June 2021), 2018.

Grandl, F., Zeitz, J. O., Clauss, M., Furger, M., Kreuzer, M., and Schwarm, A.: Evidence for increasing digestive and metabolic efficiency of energy utilization with age of dairy cattle as determined in two feeding regimes, Animal, 12, 515-527, https://doi.org/10.1017/S1751731117001823, 2017. 
Grandl, F., Furger, M., Kreuzer, M., and Zehetmaier, M.: Impact of longevity on greenhouse gas emissions and profitability of individual dairy cows analysed with different system boundaries, Animal, 13, 198-208, https://doi.org/10.1017/S175173111800112X, 2019.

Groeneveld, E., Kovač, M., and Mielenz, N.: VCE User's Guide and Reference Manual, version 6.0, Institute of Farm Animal Genetics, Neustadt, Germany, 2010.

Handcock, R. C., Lopez-Villalobos, N., McNaughton, L. R., Back, P. J., Edwards, G. R., and Hickson, R. E.: Positive relationships between body weight of dairy heifers and their first-lactation and accumulated three-parity lactation production, J. Dairy Sci., 102, 4577-4589, https://doi.org/10.3168/jds.2018-15229, 2019.

Herold, P.: Entwicklung eines nachhaltigen Zuchtprogramms “Ziegen für den ökologischen Landbau" [Development of a sustainable breeding program "Goats for Organic Farming"], Universität Hohenheim, Stuttgart, available at: http://orgprints.org/ 30004/ (last access: 25 June 2021), 2016.

Herold, P., Keller, M., and Valle Zárate, A.: Situationsanalyse süddeutscher Erwerbsziegenhalter [Situation analysis of the South German goat farmers], in: 9. Wissenschaftstagung Ökologischer Landbau, University of Hohenheim, Stuttgart, Germany, available at: http://orgprints.org/9420/ (last access: 25 June 2021), 2007.

Herold, P., Wolber, M. R., Kettnacker, H., and Droessler, K.: Potential for a routine health and robustness monitoring in dairy goats, in: ICAR-Conference 2017, 12-16 June 2027, Edinburgh, Scotland, 2017.

Herold, P., Mendel, C., Wenzler, J.-G., Götz, K. U., and Hamann, H.: Aufbau einer Zuchtwertschätzung bei Milchziegen [Establishment of a breeding value estimation for dairy goats], Züchtungskunde, 90, 195-205, 2018.

Herold, P., Wolber, M.-R., and Hamann, H.: Projekt GoOrganic: Entwicklung eines nachhaltigen Zuchtprogramms "Ziegen für den Ökologischen Landbau" [Project GoOrganic: Development of a sustainable breeding program "Goats for Organic Farming"], in: Int. Bioland Schaf- und Ziegentagung, Bautzen-Schmochtitz, Germany, 18-20 November 2019, 2019.

IFOAM: Principles of organic agriculture preamble, International Federation of Organic Agriculture Movements (IFOAM), available at: https://www.ifoam.bio/sites/default/files/poa_english_ web.pdf (last access: 26 June 2021), 2015.

Kern, A.: Aktuelle Situation der Erwerbsmilchziegenhaltung in Baden-Württemberg, in: Fachgespräch Ziegenzucht und Ziegenhaltung [Current situation of commercial dairy goat husbandry in Baden-Württemberg, in: Expert talk on goat breeding and goat keeping], Nürtingen, Germany, 20 March 2019.

Knapp, J. R., Laur, G. L., Vadas, P. A., Weiss, W. P., and Tricarico, J. M.: Invited review: Enteric methane in dairy cattle production: quantifying the opportunities and impact of reducing emissions, J. Dairy Sci., 97, 3231-3261, https://doi.org/10.3168/jds.20137234, 2014.

Koeck, A., Jamrozik, J., Schenkel, F. S., Moore, R. K., Lefebvre, D. M., Kelton, D. F., and Miglior, F.: Genetic analysis of milk $\beta$-hydroxybutyrate and its association with fat-to-protein ratio, body condition score, clinical ketosis, and displaced abomasum in early first lactation of Canadian Holsteins, J. Dairy Sci., 97, 7286-7292, https://doi.org/10.3168/jds.2014-8405, 2014.
König, S. and May, K.: Invited review: Phenotyping strategies and quantitative-genetic background of resistance, tolerance and resilience associated traits in dairy cattle, Animal, 13, 897-908, https://doi.org/10.1017/S1751731118003208, 2019.

Le Cozler, Y., Lollivier, V., Lacasse, P., and Disenhaus, C.: Rearing strategy and optimizing first-calving targets in dairy heifers: a review, Animal, 2, 1393-1404, https://doi.org/10.1017/S1751731108002498, 2008.

Lehmann, J. O., Mogensen, L., and Kristensen, T.: Early lactation production, health, and welfare characteristics of cows selected for extended lactation, J. Dairy Sci., 100, 1487-1501, https://doi.org/10.3168/jds.2016-11162, 2017.

LKV Bayern: Milchleistungsprüfung in Bayern 2020 [Milk performance testing in Bavaria 2020], Prüfungszeitraum 1 January-31 December 2020, Landeskuratorium der Erzeugerringe für tierische Veredelung in Bayern e.V., available at: https://www.lkv.bayern.de/wp-content/uploads/2021/03/ 20210310_MLP-Jahresbericht-2020_Online_compressed.pdf (last access: 26 June 2021), 2020.

Llonch, P., Hoffmann, G., Bodas, R., Mirbach, D., Verwer, C., and Haskell, M. J.: Opinion Paper: Measuring livestock robustness and resilience: are we on the right track?, Animal, 14, 667-669, https://doi.org/10.1017/S1751731119003306, 2020.

Manek, G., Simantke, C., Sporkmann, K., Georg, H., and Kern, A.: Systemanalyse der Schaf- und Ziegenmilchproduktion in Deutschland [System analysis of sheep and goat milk production in Germany], available at: http://orgprints.org/31288/1/3128812NA110-bioland-fischinger-2017-systemanalyse-schafziege.pdf (last access: 26 June 2021), 2017.

Mäntysaari, P., Mäntysaari, E. A., Kokkonen, T., Mehtiö, T., Kajava, S., Grelet, C., Lidauer, P., and Lidauer, M. H.: Body and milk traits as indicators of dairy cow energy status in early lactation, J. Dairy Sci., 102, 7904-7916, https://doi.org/10.3168/jds.201815792, 2019.

Mohd Nor, N., Steeneveld, W., van Werven, T., Mourits, M. C. M., and Hogeveen, H.: First-calving age and first-lactation milk production on Dutch dairy farms, J. Dairy Sci., 96, 981-992, https://doi.org/10.3168/jds.2012-5741, 2013.

Moog, U., Gernand, E., and Lenz, H.: Euter- und Milchbefunde in Thüringer Milchziegenbetrieben [Udder and milk findings in Thuringian dairy goat farms], in: Abstracts der internationalen Tagung, Tiergesundheit kleiner Wiederkäuer, Tierärztliche Praxis Großtiere, Sellin, Rügen, Germany, 2325 May 2012, 2012.

Mucha, S., Mrode, R., Coffey, M., and Conington, J.: Estimation of genetic parameters for milk yield across lactations in mixed-breed dairy goats, J. Dairy Sci., 97, 2455-2461, https://doi.org/10.3168/jds.2013-7319, 2014.

Rahmann, G.: Ökologische Schaf- und Ziegenhaltung - 100 Fragen und Antworten für die Praxis [Organic sheep and goat husbandry - 100 questions and answers for practice], available at: http:// orgprints.org/12971/ (last access: 26 June 2021), 2007.

Rensing, S., Schierenbeck, S., and Segelke, D.: Neue Merkmale in der Milchrinderzucht [New traits in dairy cattle breeding], in: Rinderzucht Informationsveranstaltung (VIT), Verden, Germany, 12 February 2019, 2019.

Ringdorfer, F.: Mehrjähriges Durchmelken der Ziegen, Vorund Nachteile [Perennial extended milking of goats, advantages and disadvantages], in: 4. Fachtagung für Ziegenhaltung, 
Lehr- und Forschungszentrum für Landwirtschaft, RaumbergGumpenstein, Austria, 21-24, 2009.

Römer, A., Boldt, A., and Harms, J.: Position paper: One calf per cow and year - not a sensible goal for high-yielding cows from either an economic or an animal welfare perspective, Landbauforsch. J. Sust. Org. Agr. Syst., 70, 39-44, available at: https: //d-nb.info/1214672515/34 (last access: 26 June 2021), 2020.

Rupp, R., Clément, V., Piacere, A., Robert-Granié, C., and Manfredi, E.: Genetic parameters for milk somatic cell score and relationship with production and udder type traits in dairy Alpine and Saanen primiparous goats, J. Dairy Sci., 94, 3629-3634, https://doi.org/10.3168/jds.2010-3694, 2011.

SAS 9.4: SAS Version 9.4, Statistical Analysis System Institute, Cary, North Carolina, USA, 2017.

Sawa, A., Siatka, K., and Krężel-Czopek, S.: Effect of age at first calving on first lactation milk yield, lifetime milk production and longevity of cows, Ann. Anim. Sci., 19, 189-200, https://doi.org/10.2478/aoas-2018-0044, 2019.

Schuiling, E.: Duurmelken bij geiten [Extended milking in goats], Animal Science Group, Wageningen University \& Research, Wageningen, The Netherlands, Rapport 97, available at: http: //library.wur.nl/WebQuery/wurpubs/fulltext/42847 (last access: 26 June 2021), 2007.

Schuster, J. C., Barkema, H. W., de Vries, A., and Kelton, D.: Invited review: Academic and applied approach to evaluating longevity in dairy cows, J. Dairy Sci., 103, 11008-11024, https://doi.org/10.3168/jds.2020-19043, 2020.

Sehested, J., Gaillard, C., Lehmann, J. O., Maciel, G. M., Vestergaard, M., Weisbjerg, M. R., Morgensen, L., Larsen, L. B., Poulsen, N. A., and Kristensen, T.: Review: Extended lactation in dairy cattle, Animal, 13, 65-74, https://doi.org/10.1017/S1751731119000806, 2019.

Torres-Vázquez, J. A., Valencia-Posadas, M., Castillo-Juárez, H., and Montaldo, H. H.: Genetic and phenotypic parameters of milk yield, milk composition and age at first kidding in Saanen goats from Mexico, Livest. Sci., 128, 147-153, https://doi.org/10.1016/j.livsci.2009.06.008, 2009.

Volkmann, N., Kemper, N., and Römer, A.: Impacts of prepubertal rearing intensity and calf health on first-lactation yield and lifetime performance, Ann. Anim. Sci., 19, 201-214, https://doi.org/10.2478/aoas-2018-0051, 2019. von Korn, S., Trautwein, H., and Jaudas, U.: Landwirtschaftliche Ziegenhaltung [Agricultural goat farming], in: 2. neu bearbeitete Auflage, Eugen Ulmer KG, Stuttgart, Germany, 2013.

Wangler, A., Blum, E., Böttcher, I., and Sanftleben, P.: Lebensleistung und Nutzungsdauer von Milchkühen aus Sicht einer effizienten Milchproduktion [Productive life and longevity of dairy cows on the basis of efficiency of milk production], Züchtungskunde, 81, 341-360, 2009.

Wolber, M.-R., Hamann, H., and Herold, P.: Durch- und Dauermelken bei Milchziegen, 1. Mitteilung: Analyse der systematischen Effekte auf Milchleistungsmerkmale [Continuous and extended milking in dairy goats, 1. Communication: Analysis of systematic effects on dairy traits], Züchtungskunde, 90, 379-397, 2018.

Wolber, M.-R., Hamann, H., and Herold, P.: Durch- und Dauermelken bei Milchziegen, 2. Mitteilung: Genetische Analyse von Milchleistungsmerkmalen [Continuous and extended milking in dairy goats, 2. Communication: Genetic analysis of dairy traits], Züchtungskunde, 91, 129-140, 2019.

Zumbach, B. and Peters, K. J.: Zuchtprogrammgestaltung bei der Bunten Deutschen Edelziege [Breeding program formation for the German Fawn Dairy Goat], Züchtungskunde, 79, 184-197, 2007.

Zumbach, B., Peters, K. J., Emmerling, R., and Sölkner, J.: Development of a test day model for milk sheep and goats under unfavourable structural conditions in Germany, EAAP-Book of Abstracts No. 10, in: 55th Annual Meeting of the European Association for Animal Production, Bled, Slovenia, 5-8 September 2004, 237 pp., 2004.

Zumbach, B., Tsuruta, S., Misztal, I., and Peters, K. J.: Use of a test day model for dairy goat milk yield across lactations in Germany, J. Anim. Breed. Genet., 125, 160-167, https://doi.org/10.1111/j.1439-0388.2007.00718.x, 2008. 